\title{
ACRE MADE IN AMAZONIA, DESIGN FOR THE DEVELOPMENT OF SUSTAINABLE COMMUNITIES
}

\author{
Eugenia Chiara \\ Politecnico di Milano \\ eugenia.chiara@gmail.com \\ Giuliano Simonelli \\ Politecnico di Milano \\ giuliano.simonelli@polimi.it \\ Valentina Auricchio \\ Politecnico di Milano \\ valentina.auricchio@polimi.it
}

\begin{abstract}
O$ design pode ser uma força motriz para o desenvolvimento local de comunidades produtivas, permitindo-Ihes atingir a liberdade para inovar, respeitando a sua tradição cultural e de valores. Em nossa experiência, este processo requer tempo e empatia, compreensão e apoio profissional. O Projeto Acre é uma ação de desenvolvimento local sustentável com o objetivo de dar apoio para as comunidades produtivas auto-sustentáveis no setor de móveis de madeira.

Através de atividades com foco na educação e desenvolvimento de produtos, o projeto deu origem ao resgate da identidade local que reuniu diferentes realidades produtivas e colaborou para o desenvolvimento de produtos exclusivos, com o apoio e base na experiência industrial italiana. A iniciativa engajou a comunidade que trabalha de forma colaborativa e que compete no mercado de forma harmoniosa contribuindo para o desenvolvimento econômico e social da região.

Todos os processos de produção deste projeto foram concebidos com a premissa do respeito aos recursos sociais e ambientais da região, reforçando a importância das comunidades auto-sustentáveis. Ao longo do curso especialistas italianos e brasileiros, trabalharam em conjunto nas fases de investigação, educação, produção, engenharia e comercialização das cinco linhas de móveis.

Os principais fatores de inovação do projeto podem ser sintetizados da seguinte forma:

- Transferência de conhecimento das capacidades de inovação através de um processo de formação profissional, reunindo os estudantes $e$ as empresas locais, criando um diálogo direto entre agentes de mudanças $e$ produtores;

- Consultoria tecnológica para as empresas durante a fase de engenharia, permitindo o uso de recursos locais disponíveis para otimizar os processos de produção.
\end{abstract}


- Criação de um consórcio de empresas relacionadas ao setor de madeira e móveis, trazendo um conjunto de produtores da região, criando uma marca local permitindo o acesso ao mercado nacional.

- Investigação e desenvolvimento de uma identidade visual local baseada em uma atividade de co-design, trazendo de volta à vida símbolos tradicionais da cultural Acreana.

- A criação de uma escola local para a educação e capacitação do processo criativo, inovação e design de mobiliário.

O conceito do Projeto Acre, made in Amazonia, pode ser replicado para diversos segmentos como um incentivador do desenvolvimento préindustrial.

Keywords: madeira, marca local, a sustentabilidade, a escola de design

\section{INTRODUCTION}

The Acre design process is a complex and rich project, conceived by the government of the Brazilian state of Acre and implemented by a coordinated interdisciplinary and international team of researchers, designers, technicians. The main goal of the project lies in creating a local productive district based on sustainability and creative economy where design plays the role of an engine for development. In this process different design branches were involved: design for sustainability, strategic design, product and communication design, design for internationalization and social design (see Figure 1).

Design for sustainability had an important role in the design of the devices (products and services) in order to follow sustainable development rules, understood as being "the reorientation of the social behavior in favor of the demand of products, services and behaviors that answer to the social necessities of welfare using an amount of less environmental resources and creating more balanced economic-social relations" (Vezzoli C., Manzini And, 1998). Strategic design applied to the development of a local economy through participative methods gives form to building a network of different socio-economic actors hence promoting local partnerships. The capabilities of strategic design within the objectives of design for sustainability gives birth to what are defined as methodologies of Strategic Design for Sustainability. These capabilities can be divided in three branches of design, the strategic one, the design of communication and the design for sustainability enclosing the primordial necessities of the initiatives in which design can be involved. The Contribution of strategic design consists in the creation of local networks and partnerships, consortium of companies related to specific materials or productive fields, promoting interactions between producerconsumer and the qualification of products and productive processes to reach more demanding markets, the incubation and consulting of new activities. The contribution of communication design is related to the construction of a collective visual identity that enhances the characteristics of the territory. In particular through processes of codesign it is possible to bring out relevant elements of local identity and translate them into forms, motifs and colors which will immediately define an original visual grammar. This process ends with the project of the brand identity of the region that can be used within different productive sectors, channels and product families. The contribution of 
product design consists in the creation of products that are carrying a history, related to the local identity and that use in a responsible way natural resources, in this case the different kinds of wood, respecting and preserving the biodiversity of the forest. The contribution of design for sustainability consists in the definition of the priorities in the environment and social orientation in the development and/or evolution of determined solutions and the evaluation and verification of the environment and social validity of a determined solution, in this particular case related to the choice of raw material and of the producer.

Design acts in all these fields as an innovation driver for a sustainable local economy, the designer can be considered a social actor, not just a professional, that interacts with raw material producers, small enterprises and artisans, shops and distributors, final consumers and institutions. It has the important role of network creator, company innovator and creator of sustainable productive chains. The role of the designer is also fundamental in internationalization processes, that can be in this historical moment of crisis, for small enterprises and artisans a way to survive in an evermore competitive and global market. They no longer have contact with final users, which often live in other territories and belong to different cultures, and do not have the tools to connect and innovate at an international level.

Since the early 70's, designers around the world have been working in this arena with the aim to help artisans reach new markets and learn how to develop autonomous innovative processes. Through transfer of knowledge and support in creating networks, designers have shown unique capabilities that can support internationalization processes of territories worldwide by identifying new markets and interpreting cultures, identifying new technologies and identifying new cultural contexts. These kind of projects show that designers are capable not only to develop new products and services, but they also can build global value chains that allow artisans to access new markets and transfer innovation capabilities to communities enabling them to connect with partners worldwide.

\section{DEVELOPMENT}

The perspective of the Acre project is the one of social design. Social design articulates concepts and elements of solidarity economy, of information and economic systems with a territorial base turned to the sustainable development of a community with the creation of jobs, income, critical consumption and civil rights, with attitudinal changes and changes in paradigm, aiming to become an influencer of a future public policy.

The work of the designer in these contexts is that of a bridge between tradition and modernity connecting production areas to global markets. Design is therefore seen as a tool for development with a strategic role in encouraging new models of development, ecologically and socially sustainable. The role of the designer is also to preserve cultural resources, to catalogue and analyze craft traditions to hand them down and transfer them to a wider audience.

A social designer can act in this field as a connector of different actors on a local system for creating new chains, products and services, as a local strategist that can build and implement visions of a sustainable local development, as an incubator of new activities and economic enterprises (see Figure 2). 
Acre is the leader region of environmental awareness linked to the Amazon forest, begun by the action of the famous environmentalist Chico Mendes and carried forward by governments that have followed in subsequent decades. The idea launched by Mendes and that has become a cornerstone of sustainable development of the region lies in the responsible use of forest resources, avoiding the destruction linked to the fires that were going to turn the forest into farmland. The region of Acre starts the conversion process for an economic and industrial development from wood supply chain, before introducing the concept of "certified forest" dedicating forest areas to the extraction of wood according to the principle of "manejo florestal" which defined the cutting of an essence only when there were three plants younger of the same type, to preserve biodiversity. Then the government created the "Polo Moveleiro" the productive center of Rio Branco in the field of furniture that brings together the different companies in the area in a manufacturing district characterized by the sharing of infrastructure as a driver, a prototyping workshop, a showroom and an area related to education and research. This center was the main promoter of "Acre design" giving birth to the "Acre, made in Amazonia" brand that identifies products developed in accordance with principles of environmental and social sustainability, first applied to the wood and furniture sector and then spread also to other productive sectors linked to local materials such as rubber or bamboo. In parallel, ZPE project, a frank export processing zone, was developed to attract Brazilian companies and international enterprises to implant there, in order to allow them to process on-site raw materials and sell high value-added products instead of selling off only raw forest materials. To enhance human capital of the state and create a new generation of technical and creative people who can act as the engine for this type of development the government began the implantation of a design school. The government of Acre is pursuing a far-sighted and ambitious project that binds the value of local raw materials to the creation of companies engaged in the production of high value-added products that can drive the region's economy and create jobs and social and cultural innovation.

The Acre design project aims to create a Design system related to the territory, its cultural identity and its industrial development. The Acre Design project began in 2011 with the development of a first experimental line of products in the wood furniture sector and has grown over the years transforming it into a more ambitious project that works on educational, political and business innovation involving the entire Acre region, its businesses and creative talents. In the first phase concepts of the different lines of the collection "Acre, Made in Amazonia" were developed within a training process that involved students of the faculty of architecture, artists and woodworkers. Together they identify the different souls of the local culture and developed a "local visual grammar" which was later an inspiration for the design of the furniture and in their communication (see Figure 3). Two internationally renowned designers lead the design workshop, with students working on objects of contemporary design but impregnated with the local culture. A specialist in the furniture sector directed the prototyping phase through a technical training process with the businesses involved in the venture. An Italian designer created the brand and the visual communication, working side by side with local artists (see Figure 4). Each line contains a world within it, which starts by choosing its proper name. These names, which are traditional and symbolic (Jiboia, a serpent sacred to the Forest peoples; Palafita, names of traditional houses located on the rivers), refer to archetypical 
characters among the local population: the rubber extractor, the pajé (wise Indian chief) and the river fisherman. The catalogue photos present these worlds, approximating Acre, with its beauty and its products, to a more industrial world, but without ever forgetting the values of sustainability, ecology, and respect for the forest (see Figure 5).

The brand "Acre, made in Amazonia", created by the government of Acre, joins together various businesses that participated in the project and aims to be the first seed of a productive development of Amazonia, always striving to be sustainable, whether in the environmental sense, but mostly socially sustainable. Between 2012 and 2014 the collection was exhibited in different cities, in Rio Branco, at the Placido Castro theater, in the creative economy festival of Sao Paulo, at the furniture fair in Milan and at the same time the book linked to "Acre, made in Amazonia" research was edited and distributed (see Figure 6).

In parallel the work with artisans and students continues. On the one hand the team of works on engineering and industrializing the collection and formalizing an agreement between producers related to the brand "Acre, made in Amazonia" and an Italo-Brazilian research group giving form to the political-pedagogical structure of the future technical design school of Acre. Currently, the collection is working on distribution matters and the school begins to work through the provision of professional courses in the area of design.

The main results of this project are represented on one hand by the work done with the companies, which led to the creation of a collection of a brand and a consortium of companies, on the other hand from the work with local institutions to formalize the school and the training of young people and technicians. The Acre design project linked to the wood and furniture sector is meant to be only the first step of the sustainable economic development of the region of Acre. The marketing project that is emerging must be a stimulus to the consolidation of the consortium of the wood furniture industry manufacturers. The goal of the government is to attract business in the region to create a working production center that will work also in the field of rubber, bamboo, textiles and ceramics. The school expects to start operating at full power and be integrated in the Brazilian professional education system.

\subsection{Figures}

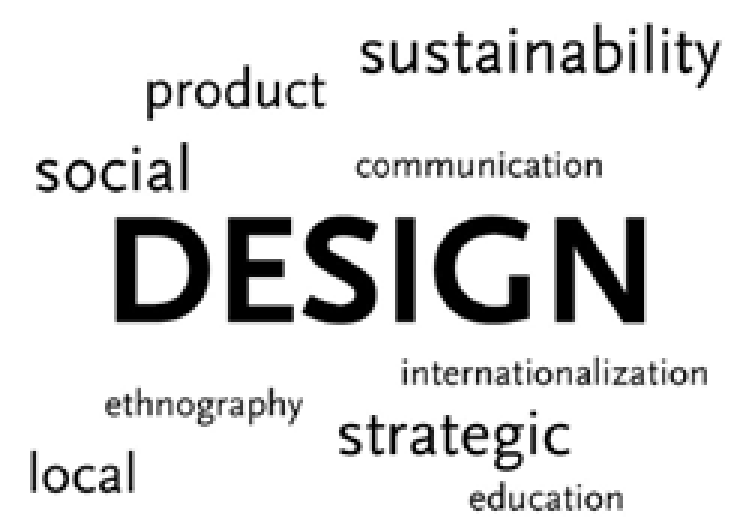

Figure 1 - "Disciplines map"

Source: Elaborated by the author, based on the research done. 


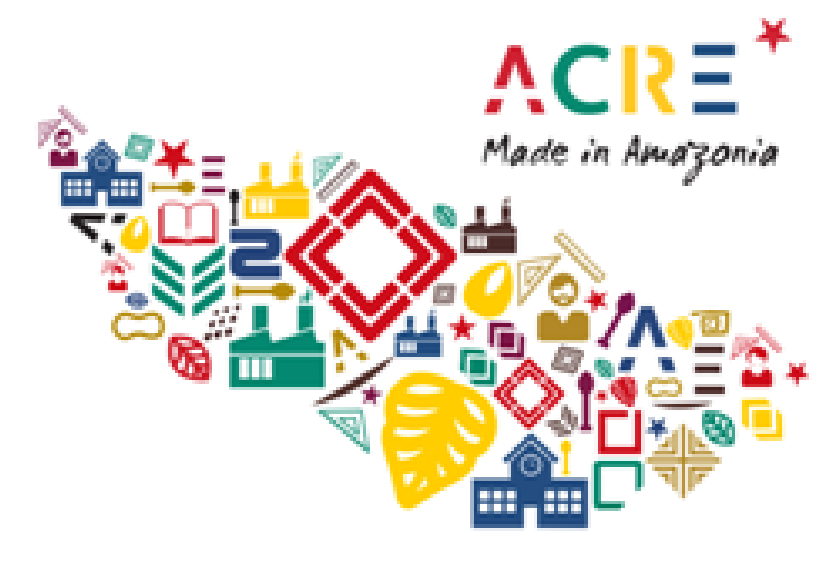

Figure 2 - "Acre design infographic".

Source: Elaborated by the author, based on the research done.

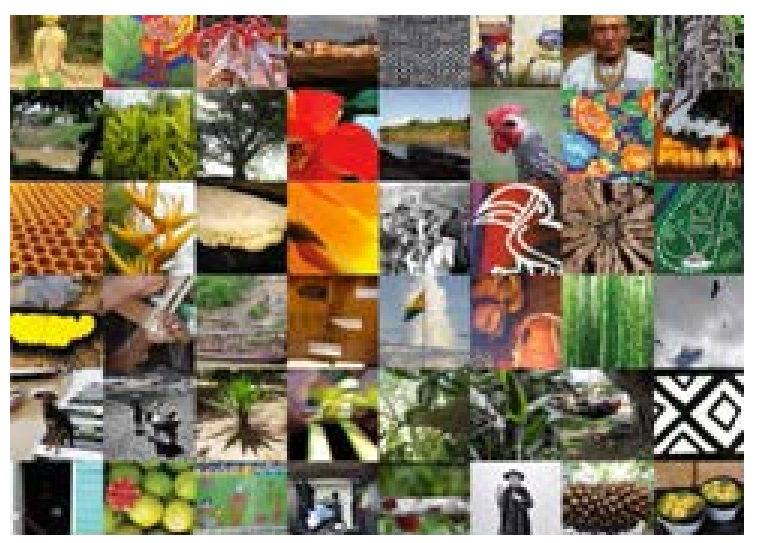

Figure 3 - "Acre identity".

Source: Elaborated by the author, based on the research done.

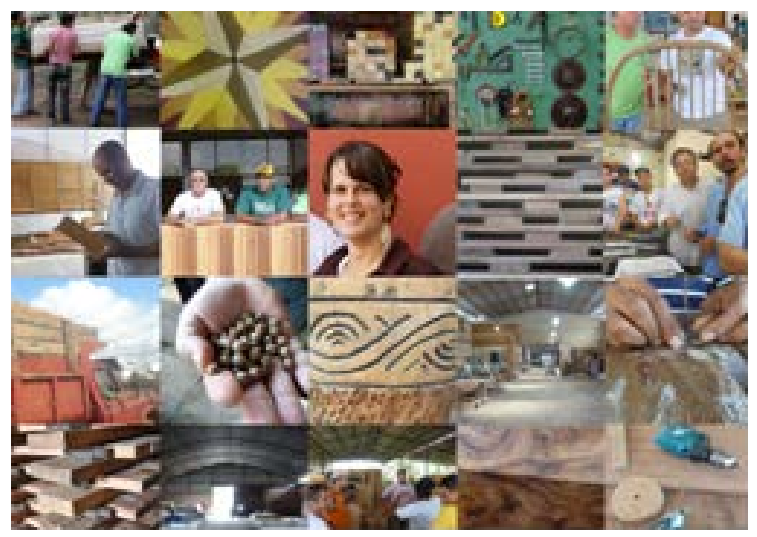

Figure 4 - "Design process".

Source: Elaborated by the author, based on the research done. 


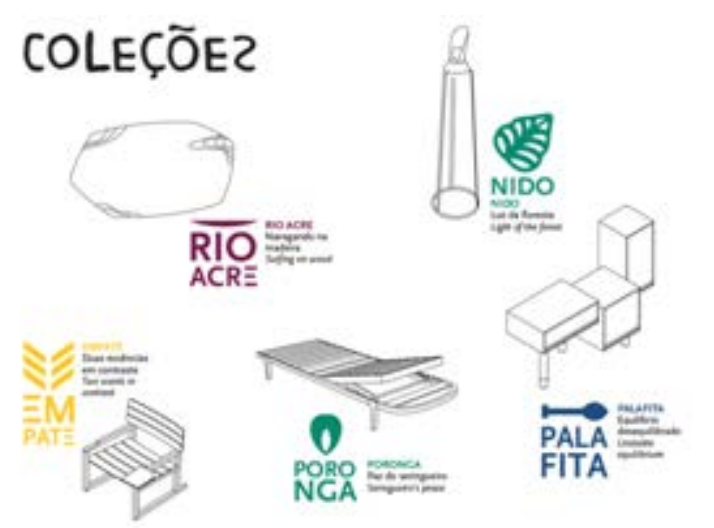

Figure 5 - "Acre products".

Source: Elaborated by the author, based on the research done.

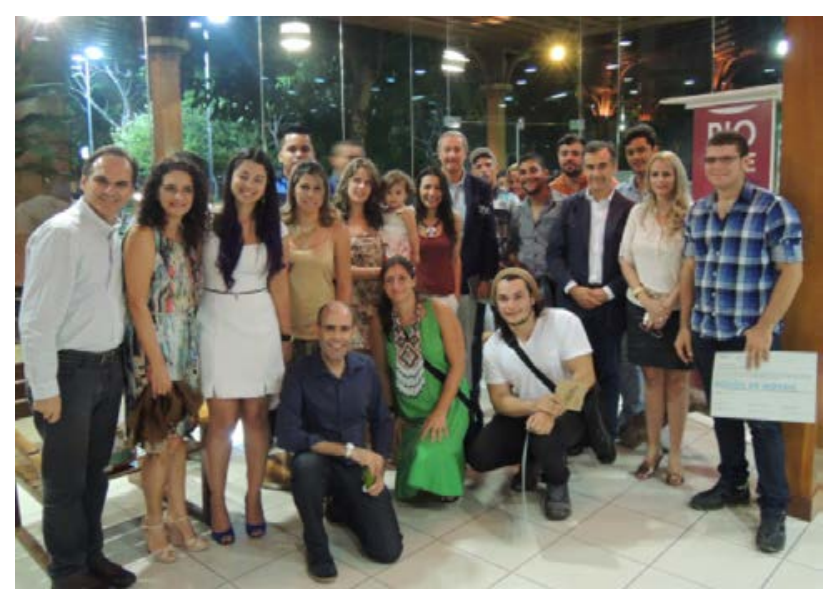

Figure 6 - "Acre made in Amazonia exhibition in Rio Branco".

Source: Elaborated by the author, based on the research done.

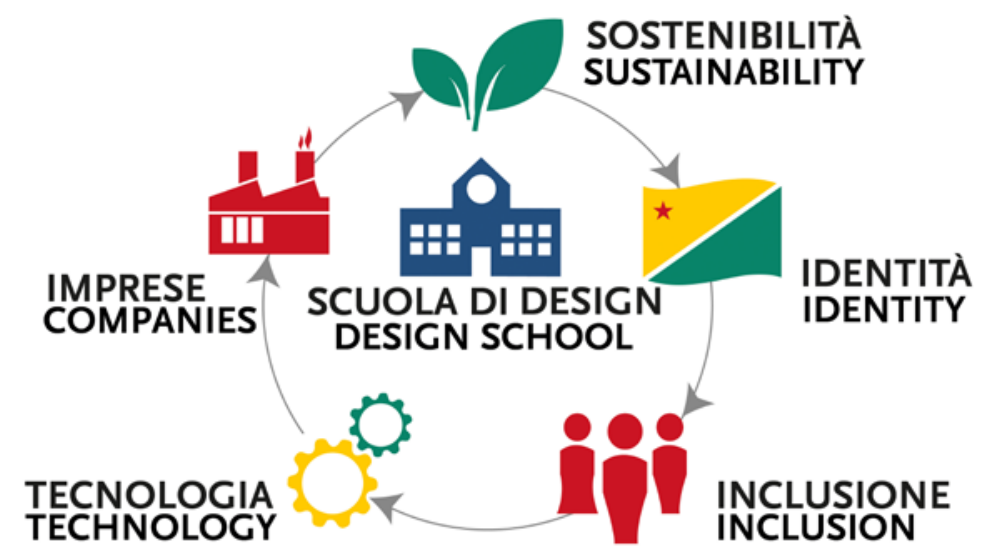

Figure 7 - "Design school key principles"

Source: Elaborated by the author, based on the research done. 


\section{CONCLUSION}

The main innovation factors of the project can be synthesized as following:

\& knowledge transfer of innovation capabilities through professional training processes, bringing together students and local companies creating a direct dialog between change agents and producers;

$\&$ technological consulting to companies in the engineering phase in order to allow the local realities to optimize their production processes with respect to the local productive capabilities;

\& creation of a consortium of companies related to the wood and furniture sector, bringing a set of local producers under a unique local brand and allowing them to access far away markets;

$s<$ research and development of a local visual identity based on a co-design activity, bringing back to life traditional graffiti and symbols;

s< setting the base for future local schools in the field of creativity, innovation and furniture design.

This project can be a model that can be replicated in other contexts as an accelerator of development in pre industrial contexts both in relation with local companies and also in the education processes. The methodologies used during the first research phase and the training process through tools and codified processes and exercises such as mood boards, five hat exercise, trend studies, scenarios, positioning diagrams can build a design process that can be applied in different territories and contexts and related to different materials, companies and supply chains (see Figure 7).

The educational vision of the technical school of design is an original model, formulated in relation to a specific context but that can be adapted in the different states of Brazil to integrate and modernize the methods of professional schools such the Lices de Artes a Oficios which need a redefinition and adaptation to the contemporary reality or also being a first seed of a university of design based on sustainability principles. This kind of training model can also be translated into different countries and continent, such as Asia and Africa and countries that are entering the industrialization and decide to do it in a sustainable way.

\section{REFERENCES}

ACRE, Governo do Estado. Zoneamento Ecológico-Econômico do Estado do Acre, fase II. Documento Síntese. 2. Rio Branco, SEMA, 2010.

Acre, GOVERNO DO ESTADO. Fundação de Tecnologia do Estado do Acre. Atlas do Estado do Acre. Rio Branco, Governo do Estado do Acre, Fundação de Tecnologia do Estado do Acre, 2008.

ACRE CERTIFICADO. A sociedade construindo uma economia sustentável. Rio Branco, Governo do Estado do Acre, s/d.

AURICCHIO, Valentina e Faust, Jurgen (edited by). Design for Social Business: setting the stage. Milano, Italia: Lupetti Editore, 2011. 
AURICCHIO, Valentina. Comunità di Design. Milano, Italia, 11 Ottobre, p. 23: Nova 24, II Sole 24 Ore, 2010.

AURICCHIO, Valentina e Collina, Luisa e Simonelli, Giuliano (edited by). DIMI, Design Innovation Made in Italy. Connecting India and Italy through design. Milano, Italia: Edizioni POLI.design, 2009.

AURICCHIO, Valentina. International Design Governance: tools and methods for building and managing global value chains. Barcelona, Spain: EDULEARN09, IATED Conference. 2009.

AURICCHIO, Valentina. Design education. Internationalization of design research and education centers. Madrid, Spain: ICERI Conference. 2008.

AURICCHIO, Valentina. (2007) INTERNATIONAL DESIGN ROUTES: Design strategies for international networks of designers and craft enterprises. Sydney, Australia:

ConnectED, Conference, 2007.

AURICCHIO Valentina, Internazionalizzazione di centri di formazione e ricerca di design: promozione di filiere internazionali di progetto, PhD, XX ciclo, Politecnico di Milano, 2007.

ARRUDA Marcos. Sócioeconomia solidária: desenvolvimento de baixo para cima. Rio de janeiro: ed. Pacs, 1998.

BALARAM S, Thinking Design, National Institute of Design, Ahmedabad: 1998.

BONSIEPE Gui, Peripheral Vision, Escola Superior de Desenho Industrial (ESDI) Brazil: 2004.

BORGES, Adélia. Design + artesanato. O caminho brasileiro. São Paulo: Editora Terceiro Nome, 2011.

CHAVES, Liliane, Design for environmental sustainability: design strategies, methods and tools in the furniture sector, PhD, XIX ciclo, Politecnico di Milano, 2007.

CHIARA Eugenia, Fair design. Economia solidale e design socialmente sostenibile, una collaborazione possibile, PhD, XX ciclo, Politecnico di Milano, 2008.

CHIARA Eugenia, Carniatto Izamara Design e economia solidale: il confronto tra I'esperienza italiana e quella brasiliana, P\&D Design, Curitiba, 2007.

CHIARA Eugenia, Sole, vento, acqua, vegetazione e tecnologie avanzate. Matrici di un nuovo approccio progettuale al territorio, architettura e design strategico, Milano:

Cangemi Editore, 2007.

FREIRE, Paulo. Pedagogia da autonomia. Saberes necessários à prática educativa. São Paulo: Paz e Terra, 1998.

KASTURI Poonam Bir, Designing Freedom, Design Issues, Autumn 2005, Vol. 21, No. 4, Pages 68-77.

KRUCKEN Lia, Design e território. Valorização de identidades e produtos locais, ed. São Paulo: Ed. Nobel, 2009.

MANCE, E. A. A revolução das redes como estratégia de libertação popular. Cepat, $n$. 51, 1999. 
MANCE, e. A. Aspectos filósoficos das redes de colaboração solidária. Contato, ed. Especial, 1999.

MANCE, euclides a. A revolução das redes: a colaboração solidária como uma alternativa pós-capitalista à globalização atual. Petrópolis: vozes, 1999.

MANCE, Euclides a. Como organizar redes solidárias. Rio de janeiro: dp\&a, 2002.

MANCE, Euclides a. Redes de colaboração solidária, aspectos econômico-filosóficos: complexidade e libertação. Petrópolis: vozes, 2002. 364p.

MANZINI, Ezio. O desenvolvimento de produtos sustentáveis: os requisitos ambientais dos produtos industriais. São Paulo: Ed. USP, 2002.

MANZINI E., A cosmopolitan localism. Prospects for a sustainable local development and the possible role of design, 2005.

Manzini E., Design As A Tool For Environmental And Social Sustainability, in Design Issues In Europe Today, The Bureau of European Design Associations - BEDA White Book, ed. By Stuart Macdonald, NL: The Publishers, 2004.

MARGOLIN, Victor and Sylvia Margolin, A 'Social Model' of Design: Issues of Practice and Research, Design Issues Vol. 18, No. 4: 24-30., 2002.

MARGOLIN, Victor, The Product Milieu and Social Action, in Discovering Design: Explorations in Design Studies, edited by Richard Buchanan and Victor Margolin, pp. 121-145, Chicago: University of Chicago Press., 1995.

PAPANEK Victor, Design for the real world, Thames and Hodson, London: 1972.

PAPANEK Victor, The green imperative: ecology and ethics in design and architecture, London: Thames and Hudson, 1995.

RAZETO, Luis. Economia de solidariedade e organização popular. In: gadotti, m., gutierrez, f. (orgs.) Educação comunitária e economia popular. São paulo: cortez, 1993.

SIMONELLI G., COLLINA L., Generating Tools: Fighting Barriers To Innovation, in Design Issues In Europe Today, The Bureau of European Design Associations - BEDA White Book, ed. By Stuart Macdonald, The Publishers, NL, 2004.

SIMONELLI Giuliano, Auricchio Valentina. STIMULI FOR CHANGE: Projects for building territorial design systems, Methodology and Case Histories, DETM2005 conference. INDIA. 2005.

SIMONELLI Giuliano, CELASCHI Flaviano, Collina Luisa. Design for District. Progetti per un distretto. MILANO: POLIdesign Editore. 2001.

SIMONELLI Giuliano, ZURLO Francesco, Auricchio Valentina, Global Community Interactions: The Future Role Of Design In International Territorial Competition/Cooperation. MX Design Conference. MEXICO, 2005

SINGER, Paul (2002). Introdução à economia solidária. São paulo: fundação perseu abramo

SINGER, Paul; SOUZA, André Ricardo de (orgs.). A economia solidária no brasil. São paulo: contexto, 2000. 
SINGER, Paul. Economia solidária: geração de renda e alternativa ao liberalismo. Proposta, n. 72, 1997.

THACKARA, J. (2005). In the bubble: designing in a complex world. Cambridge: MIT press 